\title{
NETWORKS FINANCIAL
} INSTITUTE

\section{Working Paper}

\author{
At Indiana State University
}

\section{6-WP-12}

\section{November 2006; revised April 2007}

\section{Why Is The Profitability of Financial I nnovation So Difficult to I dentify? Innovation Clusters and Productive Opacity Kurt Dew}

\begin{abstract}
The empirical literature identifying gains from financial innovation to financial institution stockholders is sparse. The literature identifying financial firms' contributions to stockholder value resulting from long term commitment to innovation is, to our knowledge, nonexistent. Several authors note that the protection of financial engineering innovations from imitation is particularly challenging. We consider the implications for the structure of financial innovation, proposing a stylized representation of the innovative process called "the cluster hypothesis." Under the hypothesis, innovations occur in symbiotic collections of transparent "external innovations," together with opaque "internal innovations." Only the latter provide economic rents. We find evidence that innovation-induced opacity drives long run relative rewards at added risk for financial institution stockholders.
\end{abstract}

About the Author: Kurt Dew received his PhD in Economics from Texas A\&M University. He spent the subsequent 5 years as research economist with San Francisco Federal Reserve Bank, conducting research in the area of monetary and fiscal policy and financial futures. He spent the following three years serving as Senior Financial Economist at the Chicago Mercantile Exchange. He currently teaches at Griffith University in Brisbane, Australia, where he pursues research in emerging markets, asset pricing, bank innovation and regulation and corporate governance.

Keywords: financial innovation, event studies, opacity, value relevance.

\section{EL classification: G15, G21, G24, G32, K11, L11, M52, N20, 031, 033}

Original title: "How Important is Financial Innovation to Financial Institution Profitability? Financial Innovation Clusters and Productive Opacity." The author wishes to thank Teruyo Omura for able assistance, as well as Griffith University and Networks Financial Institute at Indiana State University for financial support of this project. Thanks as well to J ohn A. Tatom for helpful comments on an earlier draft.

The views expressed are those of the individual author and do not necessarily reflect official positions of Networks Financial Institute. Please address questions regarding content to Kurt Dew at k.dew@griffith.edu.au. Any errors or omissions are the responsibility of the author.

$\mathrm{NFI}$ working papers and other publications are available on NFI's website (www.networksfinancialinstitute.org). Click "Research" and then "Publications/Papers." 


\section{Why is the Profitability of Financial Innovation So Difficult to Identify? Innovation Clusters and Productive Opacity}

\section{Kurt Dew}

\section{Introduction.}

U.S. Supreme Court Justice Potter Stuart famously said of pornography, “I can’t define it, but I know it when I see it.” Perhaps the converse is true of financial innovation. We can define it, but we don’t know it when we see it. Financial innovation has indisputably been a significant, even dominant, factor in the development of modern business practice - a driving force behind economic growth in countries where financial innovation rather than imitation is the rule. Changes of the past half century in the path money takes from saver to investor, including disintermediation and change in the composition of investor portfolios, are rooted in innovation. It is difficult to imagine modern financial practice without the Theory of Efficient Markets, the Capital Asset Pricing Model, Modigliani and Miller’s work on capital budgeting, or the various developments in option theory and pricing such as the Black-Scholes and Merton Models, a short selection from a long list (c.f. Merton (1992), Miller (1986)).

Yet the existing literature provides no evidence of a contribution of the innovative tendencies of individual financial institutions themselves to their own long run stock price determination. Is the contribution of financial innovation doomed to be a sort of grey presence, having little direct impact on relative performance of individual financial institution equities? The existing empirical work answers cautiously in the affirmative. In their survey article (2004) reviewing empirical studies of innovation, Frame and White found only two dozen empirical articles addressing financial innovation, 14 of which had been written since 2000. To our knowledge, there are no articles attempting to rank 
financial institutions by their innovative tendency or to measure the effect of innovative tendency on long run market yields to the institutions' common shares.

This article proposes that the missing evidentiary link between institutional innovative capacity and long term profitability is due to a gap in the literature, not to absence of creativity within successful financial institutions or lack of contribution of innovation to the value of the shares of the creative firms. It raises the possibility that innovative capacity may be the dominant determinant of long-run financial institution

profitability within institutional control. We call our explanation "the cluster hypothesis."

The article is organized as follows. In the next section we explain the cluster hypothesis and provide a cluster example. In section three, we then summarize the financial innovation literature. In the fourth section we present summary evidence of the relationship between the tendency to innovate and long run returns to financial institutions’ common stock. Finally we conclude.

\section{The Cluster Hypothesis.}

\subsection{Description.}

This analysis differs from earlier work primarily in our view that financial institutions cannot make innovations available to the public and still successfully collect economic rents on these same innovations. Yet we also believe the presence of the profitable hidden innovations can be indirectly determined using the Heisenberg Principle. To make our case, we develop an alternative to the received theory of the relationship between financial institution innovative activity and financial institution profits, as developed by Tufano (2003) and Lerner (2006a) among others. 
Our analysis points to two good reasons why researchers have not yet identified the link between financial innovation and profitability in the case of financial institutions. First, many of the innovations of financial institutions that we, as outsiders, observe are fully explained, even promoted, to competitors in order to gain market acceptance of the innovation. This public revelation invites imitation, leaving the innovator with no direct way to profit from her creation. Informed imitators drive the rent out of the innovation. Fortunately for the fate of financial institutions, other innovations remain undisclosed. But unfortunately for outside observers, in contrast to revealed innovations, necessary secrecy leaves no direct way to determine whether these remaining innovations, completely internal to the institutions themselves, exist.

The clustering of innovations is an inevitable result of the unique structure of financial institutions and markets. Financial institutions, by definition, buy money in an open marketplace, do something to the money, and then sell money in the same open marketplace. The instruments used to buy and sell the money may be clever and new, but they must be as transparent as possible to maximize the interest of potential counterparties in the transaction. However, if the process of "doing something to the money" is made available to the public, the result is to eliminate the need for the intermediator.

A problematic aspect of the internal innovation found in the cluster is that it is developed and used without any direct external evidence of its existence other than the resulting profits. Thus innovators cannot determine whether their internal innovation has been adopted by imitators, obviating the ability to charge licensing fees and thus eliminating any possibility of profitable disclosure. 
External innovation, although producing no rent, potentially benefits the innovating firm in two ways - a relatively reliable direct benefit and a less reliable indirect benefit. The direct benefit of external innovations is that they permit innovative companies to exploit their internal innovations. By creating new ways of buying money and new ways of selling money, innovators can create the opportunity to profit from transforming the one into the other internally. Thus external innovations transform commercial practice, permitting institutions to use their new internal innovations to exploit the resulting pricing anomalies.

The indirect benefit of external innovation is the opportunity to establish innovative reputation through misdirection. Financial innovators introduce, announce and promote zero profit external Trojan Horses clustered with profitable internal innovations. The rents accruing to the internal innovation may be interpreted by the market as accruing to the announced external innovation. As profits following announced innovations become more predictable, the innovator may be able to induce the market to capitalize anticipated profits immediately following external innovations.

There are at least three benefits resulting from the opacity of other innovative activities. First, opaque innovations cannot be imitated. Second, internality creates adaptability - the necessary ability to adapt the innovation cluster as a whole to changing market conditions in a way that leaves external innovations unchanged, simple and transparent to customers. Third, opaque innovations are inevitably complex or elaborate. The asset transformation associated with innovation clusters is never inherently simple. With simple financial creations, there is no need for an intermediary. Since the external innovations in the cluster must be relatively simple to enter common use, the residual 
problems that the internal innovation must address to create the cluster as a whole are inherently highly complex and difficult to explain, perhaps leaving little alternative to opacity.

A financial institution earning a reputation for successful innovation might find that investors are willing to capitalize the imputed value of future internal innovations into its price upon the announcement of an external innovation, due to a history of rising corporate earnings following external innovations. There thus may be a tendency for financial innovators to become magicians, in the literal rather than the mythical sense. They become masters of misdirection. Financial institutions draw attention to external innovations, but it is associated internal innovations that produce value added for the innovating firm when external innovation is adopted by its counterparties.

However, reasons exist for investors to hesitate in capitalizing announced innovative tendencies. Agency problems may be associated with investor extrapolation of past evidence of hidden creative value. Agency problems may result when a former innovator realizes her claims to innovation have value separate from the actual economic rents they produce. Perhaps unsavory alternatives to waiting for returns to innovation to hit the income statement might arise.

Opacity might become a critical property of innovative financial institutions. This would occur if the propensity to innovate is a stable property of institutional culture rather than a random result occurring within many equally creative institutions. If so, such a culture would carry heavy burdens. Such innovative institutions would need to make costly adjustments to protect their hidden innovative capital. The most obvious adjustment is that an innovator would need to raise the cost of leakage to imitators. This 
adjustment might take the form of high employee compensation as well as minimization of employee numbers.

\subsection{An Example: Plain Vanilla Interest Rate Swaps, Eurodollar Futures and Swaps-Futures Arbitrage.}

In any list of financial market innovations, interest rate swaps and Eurodollar futures have a prominent position. Notional values of interest rate swap portfolios of the major banks are now substantially more than ten times the size of their loan portfolios. The trend in this ratio is upward. Futures have also become fundamentally important financial tools. Following the anticipated merger of the Chicago Mercantile Exchange and the Chicago Board of Trade, a financial futures exchange with volume twenty times the volume of the New York Stock Exchange will be created. Although swaps and futures have both been engines of wealth creation and creative solutions to problems of risk management, in the mid-1980s at major financial institutions they were external innovations, to be explained to anyone and everyone who would listen. Their value to the major financial institutions with an interest in them was not only in brokerage income or

gain from the bid-ask spread to offering the instruments individually alone, but also in the arbitrage between the two.

The arbitrage is mathematically complicated and multifaceted, involving timing issues in the appropriate estimation of both the arbitrage position and profit, as well as problems of estimating and managing the associated credit, liquidity and operational risk. This arbitrage exemplifies the three characteristics of internal innovation:

1. The process is an internal activity and can be adopted by imitators without innovators' knowledge, making licensing prohibitively expensive. 
2. The process is not determinate. More than one characterization of the arbitrage is possible and perhaps even desirable. Keeping the process internal means it will be different from one firm to another, allowing the financial version of the survival of the fittest to work on the innovation cluster. As the scale of the swaps/futures arbitrage rose over time and the margins fell, this arbitrage also benefited from modification over time, relatively easily accomplished without changing the swap or the futures agreements themselves.

3. The arbitrage is complex. Explaining it to an interested third party would be costly for both innovator and imitator.

Interest rate swaps and interest rate futures are examples of external innovations, and the purchase of one with risk offset by the sale of the other may be characterized as arbitrage. Other innovation clusters, like taking a company private, reorganizing it, then selling shares of the reorganized and rejuvenated enterprise to the public some years later, have the same structure: rent-producing internal innovations associated with two external innovations but rarely characterized as arbitrage.

There are also several historical examples of pairs of external innovations and associated arbitrage-like internal innovations where the various risks, prices or appropriate arbitrage positions were badly misjudged, with spectacular unpleasant consequences. The three major examples found in Ross (1999), Metalgesellshaft, Long Term Credit and Enron, underline the fact that internal innovation is risky.

\section{The Financial Innovation Literature.}

The existing literature may be characterized as direct observation of individual innovations announced, sometimes publicized, by financial institutions. Researchers 
identify innovations by determining that they induce departure from prior commercial practice. They assume, quite reasonably, that if something new enters common usage, somebody always benefits - the introducing firm usually among the beneficiaries. But there is no economic theory-based reason to believe that when a firm introduces an innovation, the firm is sole beneficiary of that innovation or that the innovator's benefits flow directly from the announced innovation itself. Indeed, the empirics of the direct observation literature suggest otherwise.

The financial innovation literature includes a series of articles by Tufano [c.f. (1989) (2003)] Lerner (2006a, 2006b) and more recently, Kumar and Turnbull (2006). Tufano's work is focused on the financial engineering aspect of financial innovation, rather than mechanical or information technology-related changes found in the retail end of the business of financial institutions. Tufano (2003) estimates that in the area of traded securities alone, in the period 1980 to 2001, the securities industry generated between 1200 and 1800 new types of securities. Thus there is no shortage of apparent financial innovations. Tufano identifies innovators’ long-term profitability relative to imitators. His research reveals three salient facts:

1. Innovations are expensive for the innovator, involving costs not incurred by imitators. Expenses include the costs of establishing internal teams of innovators. Notably these teams involve outsiders - costly accountants, lawyers and other experts who examine the acceptability of the changes in commercial practice resulting from using the innovation. 
2. Innovation is associated with economic rents. Tufano argues that innovators have lower long-run production costs than their imitators, permitting them to recapture their higher fixed costs.

3. A reputation for innovativeness itself produces economic rents through reputation effects on stock prices.

Tufano's examples of financial innovations, publicized without protection from imitators and often in the news due to promotion of the innovation by the introducing financial institution, may be external innovations. Tufano's long run cost advantage to observed innovation is also consistent with the possibility of profits to opaque internal innovations clustered with publicized external innovations.

Lerner's work enables us to compare innovation in finance with that in other innovative industries. He seeks instances of the immediate capitalization of the value of innovation in finance, which must therefore be different from the delayed long run effect identified by Tufano. Lerner uses sources of innovation identification external to financial institution announcements in the form of newspaper records and patent records, as do Kumar and Turnbull. This gives rise to an important distinction between the work of these authors and that of Tufano. The external validation requirement reduces the number of observed innovations substantially, changes the type of innovation being measured, and changes the type of firm being credited with innovation, when compared with Tufano's work. Innovation in this later work is not limited to financial engineering innovations or innovations by financial institutions. The reported innovations of Lerner as well as those of Kumar and Turnbull include software, equipment and information technology innovations. 
The combined Lerner and Tufano results jointly indicate investor uncertainty about the value associated with announced innovation. When the market is persuaded that external innovations are indicative of underlying future profits, those profits are capitalized at the time of the external innovation. But the weakness of observed financial innovation event effects, coupled with Tufano’s evidence that a long run profit is observable, suggests the market is chary of awarding rents to announcements of financial innovation.

Frankel's (1998) explanation for the weak association between innovation and equity "events" comes closest to ours. This argument focuses on the importance of tacit knowledge, arguing that innovation originators find it difficult to pass to others all the information necessary to fully exploit the opportunities an innovation provides. We take the argument a step further, suggesting it would be foolish for an innovator to pass to its counterparties more than the minimum information necessary to convince a counterparty of the wisdom of adopting new financial practices.

\section{Relating Financial Innovation to Profitability.}

The cluster hypothesis suggests valuable innovations are hidden. If so, the hypothesis also points to a possible means of identifying an empirical relationship between innovation and long run profitability of individual financial institutions. If resources are spent on secret innovations, innovating institutions will allocate resources differently from others. Extreme values of financial variables would be associated with abnormal decisions and thus with innovation. Further, it is likely that investors, on the other hand, associate deviations of institutions from average behavior with risk and might build a risk premium into the stock price of such deviating firms. 
Given the cluster hypothesis, internal financial innovation will most certainly not be reported directly by financial institutions. Thus internal innovation may be only indirectly observed, through otherwise inexplicable behavior of financial reports. If internal innovation is hidden, opacity itself will be evidence of innovation. Furthermore, if innovation is also the primary source of long-run economic rents, because of innovation's link to opacity, opacity will be associated with long-run profitability and risk.

Because opacity is undesirable in financial reports, imitators do not display opacity, because they find it unnecessary. They join the rush to introduce the external innovation, but without the opaque internal innovation that generates costs and associated economic rents, and thus without undesirable opacity in their financial reports. As a result, a demonstrated relationship between opacity and profitability provides a simultaneous test of abnormality as evidence of innovation and innovation as a source of profitability. We selected several variables in constructing our measure of opaque innovative behavior: Personnel Expenses, Total Assets, Loans, Deposits, Other Nonearning Assets, Interest Income, Net Interest Income, Other Non-Interest Income and employees.

Financial institutions sometimes pay their innovators more than they pay their chief executives, with public relations results that have not been pretty, to say the least. Prominent examples include John Merriweather at Salomon Bros. and Michael Milken at Drexel Burnham Lambert. High compensation might be the strongest defense an innovating firm has against imitators raiding innovative employees. By providing innovating individuals with a stake in the innovation, innovating firms may provide 
innovative people with an incentive to stay in the fold, hence preserving a company's monopoly status with regard to the innovation. At the opposite extreme, an institution might automate to the point that employees become largely obsolete, hiding innovative behavior by eliminating the potential spies. Computer programs seek out customers, deliver the product and manage the associated risk, all at a fraction of the cost of using people to accomplish these tasks. Thus extremely low ratios of compensation to assets might be an indicator of innovative activity as well.

A second possibility is size. In the process of creating transparent innovation, the distribution opportunities that size creates probably help in collection of innovationrelated rents. On the other hand, in the internal innovation process, size is possibly a liability because it increases the expense of maintaining the necessary secrecy. If so, global financial institutions might separate into two classes: human capital-driven high margin innovative firms with relatively few high-paid employees, and automated behemoths that race one another to collect the value of lower margin innovations by replacing humans with machines. Interestingly we find that size is the only selected variable that proves not to be an important factor in explaining the covariance of other financial variables, suggesting that it is not institutional size that matters, but why the institution chooses its size.

Avoiding dependence on deposits is another possible road to opaque innovative activity. Deposits are cheap, but they bring regulatory scrutiny due to the governmentprovided deposit insurance subsidy. Regulators are averse to opacity so regulatory scrutiny may be hostile to hidden innovative activity. Regulatory insistence on the right to scrutinize new activities with no associated guarantee of confidentiality is one of the 
key information leakages impeding innovation, as noted by Kumar and Turnbull. At the other extreme, deposit collection is sometimes a yield- rather than service-driven product from a customer point of view and hence susceptible to economies through automation. But the loss in transparency due to extraordinarily high ratios of deposits to assets may create risk - added liquidity risk due to depositor rate-sensitive behavior.

Non-earning assets are not popular with stockholders but might complement hidden innovative activity. Such assets may also perhaps be sold off at something close to book value, allowing an innovator to change its operations quickly as rents due to earlier innovation disappear. But stockholders, other things equal, would prefer high yield assets. Other things are never equal, of course. Hence high yield and cost differentials are inversely linked to the share of assets that are non-earning and are most likely an indicator of added risk.

Non-interest income is another indicator used. Although commission income and trading profits have always been important sources of income to financial institutions, unusually high reliance on trading profits looks risky due to the appearance that market risk is higher than average. On the other hand, unusually low reliance on trading profits might indicate liquidity risk or credit risk. Since separation of commission income from trading profits is a notoriously artificial exercise, we combined the two.

Our results show that although opacity is not identified uniquely by a single financial reporting entry, institutions can be ranked by the extent of their variation from mean values, and if opacity is thus defined, by opacity. We find that much (42\% in 1995) of the covariance of opacity-related characteristics is captured by a single opacity rating, a linear combination of characteristics that separate the innovator from the imitator. 
Table 1 identifies the financial values taken from 2002-2005 annual reports.

Table 2 explains transformations made to the variables to produce data upon which our measure of opacity is based.

Table 1

\begin{tabular}{|l|}
\hline \multicolumn{1}{|c|}{ Financial Report Categories Used } \\
\hline Total Assets \\
\hline Loans Net of Loan Loss Reserves \\
\hline Other Nonearning Assets (excluding float) \\
\hline $\begin{array}{l}\text { Deposits Due to Customers (individuals, } \\
\text { corporations and governments, excluding banks) }\end{array}$ \\
\hline Interest Income \\
\hline Net Interest Income \\
\hline $\begin{array}{l}\text { Other Operating Income (including both } \\
\text { commissions and trading gains) }\end{array}$ \\
\hline Personnel Expenses \\
\hline Employees \\
\hline
\end{tabular}

Table 2

\begin{tabular}{|l|l|}
\hline \multicolumn{2}{|l|}{ Adjusted Variables based on Financial Statement Categories } \\
\hline Natural Logarithm of Total Assets & logA \\
\hline Ratio of Loans to Total Assets & LA \\
\hline Ratio of Other Nonearning Assets to Total Assets & ONAA \\
\hline Ratio of Customer Deposits to Total Assets & DA \\
\hline Ratio of Interest Income to Total Assets & IIA \\
\hline Ratio of Net Interest Income to Total Assets & NIIA \\
\hline Ratio of Other Operating Income to Total Assets & OOIA \\
\hline Ratio of Personnel Expenses to Total Employees & PEEMP \\
\hline Ratio of Personnel Expenses to Total Assets & PEA \\
\hline $\begin{array}{l}\text { Gamma Transformation of Personnel } \\
\text { Expenses/Employees }\end{array}$ & TransPE \\
\hline
\end{tabular}

Total Assets tests as non-normal, a problem rectified by taking the natural logarithm.

Other balance sheet and income variables were ratios of the reported number in question

to Total Assets. The objective of using the ratios was to reduce correlation of the variables with asset size. The only income figure otherwise adjusted was Personnel 
Expenses, which appears twice, first divided by number of employees and then by Total Assets.

We found the ratio of Personnel Expenditures to Employees is very difficult to extract from financial reporting data, because the number of employees is sometimes not provided at all; sometimes, number of employees is provided as a rough estimate. Contemporaneous estimates abound, however, due to the public fascination with the compensation of bankers. We used estimates contemporaneous or nearly contemporaneous with 2005 annual reports. Employee average compensation was also the sole transformed variable that failed tests for normality in every sample period. Taking the natural logarithm of average salary also did not produce a normal random variable. Excess skewness was eliminated using a gamma distribution-based transformation. However, when institutional opacity was measured using the normalized transformation, it did not change the resulting rankings of institutions in any important way, so the non-normal simple ratio of Personnel Expenditures to Employees was used to ease duplication and interpretation of our results.

Table 3 lists sample banks, organized by headquarters country. We wanted to expand the universe of financial institutions beyond those headquartered in the United States, while limiting ourselves to relatively large institutions so that a balance could be struck between financial institutions in the United States and those of other common law compliant countries, all of which are characterized by relatively few large financial institutions in global competition. We limited ourselves to the ten largest institutions in the United States (which include HSBC) and used banks with a global presence in the other countries. The implicit assumptions are: 1) Differences among financial institution 
innovative behaviors are not constrained by country headquarters location. 2) Differences in country reporting rules are not significant in measuring opacity.

Table 3

\begin{tabular}{|c|c|c|c|c|}
\hline \multicolumn{5}{|c|}{ Banks in the Sample, By Country } \\
\hline Australia & Canada & Ireland & U.K. & U.S. \\
\hline ANZ & $\begin{array}{c}\text { Bank of } \\
\text { Montreal }\end{array}$ & $\begin{array}{c}\text { Allied Irish } \\
\text { Bank }\end{array}$ & Barclays & $\begin{array}{c}\text { Bank of } \\
\text { America }\end{array}$ \\
\hline Commonwealth & $\begin{array}{c}\text { Bank of } \\
\text { Nova Scotia }\end{array}$ & $\begin{array}{c}\text { Bank of } \\
\text { Ireland }\end{array}$ & HBOS & Citigroup \\
\hline Macquarie & $\begin{array}{c}\text { Canadian } \\
\text { Imperial }\end{array}$ & & HSBC & $\begin{array}{c}\text { Goldman } \\
\text { Sachs }\end{array}$ \\
\hline $\begin{array}{c}\text { National Australia } \\
\text { Bank }\end{array}$ & $\begin{array}{c}\text { National } \\
\text { Bank of } \\
\text { Canada }\end{array}$ & & Lloyds & $\begin{array}{c}\text { JP Morgan } \\
\text { Chase }\end{array}$ \\
\hline Westpac & Royal Bank & & & Royman Bank of \\
& of Canada & & Scotland & Merrill Lynch \\
& $\begin{array}{c}\text { Toronto } \\
\text { Dominion }\end{array}$ & & & $\begin{array}{c}\text { Morgan } \\
\text { Stanley }\end{array}$ \\
\hline & & & & Wachovia \\
\hline & & & & Wells Fargo \\
\hline
\end{tabular}

Does innovation have an important effect on financial institution returns? Basic financial theory militates against a yes answer. In an efficient market, innovative institutions should simply have higher prices, rather than higher rates of return than other firms, under the Capital Asset Pricing Model (CAPM) and its variants. Our counterargument is that this innovative tendency goes uncapitalized because it is risky. Still, only if the risk cannot be diversified away would innovation appear as a separate influence on long run average returns rather than in the institutions' price levels. Our argument is that innovative global financial institutions are too few to permit the risk to be diversified away without loss of the increased anticipated return. 
We identify opacity as the absolute value of the product of the first eigenvector of the covariance matrix of our explanatory variables, multiplied by the relevant financial reporting values of these variables for each bank. The eigenvector provides the coefficients of the linear combination of the selected financial variables that best explains the covariance among the variables from bank to bank. All financial values were taken from the financial institutions’ 2005 annual reports. Multiplying the individual bank financial values from Table 2 by the appropriate parameter from the first eigenvector and summing these products gives a summary measure of the variation of each bank from the average bank, or its opacity. Since we did not want to sign the deviations, the absolute value was calculated. This provided the opacity rank of each bank. Table 4 provides the covariance matrix of the group of financial values in 2005. Tables 5 and 6 provide the associated eigenvectors and eigenvalues.

Table 4

Correlation Matrix, 2005 Transformed Values Used to Construct the Opacity Index

\begin{tabular}{|l|l|l|l|l|l|l|l|r|r|}
\hline & \multicolumn{1}{l|l}{ LogA } & LA & NEAA & IIA & NIIA & OOIA & DA & PEA & PEEMP \\
\hline LogA & 1 & -0.309 & -0.1742 & -0.1337 & 0.1060 & 0.32665 & 0.16992 & -0.24 & 0.03188 \\
\hline LA & -0.309 & 1 & -0.3200 & 0.63340 & 0.5405 & -0.4544 & 0.58013 & -0.439 & -0.7377 \\
\hline ONAA & -0.174 & -0.320 & 1 & -0.1685 & -0.005 & 0.36324 & -0.1655 & 0.540 & 0.21862 \\
\hline DA & -0.133 & 0.6334 & -0.1685 & 1 & 0.2682 & -0.1416 & 0.28261 & -0.22 & -0.1568 \\
\hline IIA & 0.1060 & 0.5405 & -0.0052 & 0.26823 & 1 & 0.07060 & 0.78635 & -0.06 & -0.5916 \\
\hline NIIA & 0.3266 & -0.454 & 0.36324 & -0.1416 & 0.0706 & 1 & -0.1932 & 0.347 & 0.26237 \\
\hline OOIA & 0.1699 & 0.5801 & -0.1655 & 0.28261 & 0.7863 & -0.1932 & 1 & -0.18 & -0.6539 \\
\hline PEA & -0.240 & -0.439 & 0.54001 & -0.2270 & -0.064 & 0.3477 & -0.1869 & 1 & 0.28242 \\
\hline PEEMP & 0.0318 & -0.737 & 0.21862 & -0.1568 & -0.591 & 0.26237 & -0.6539 & 0.282 & 1 \\
\hline
\end{tabular}

Table 5

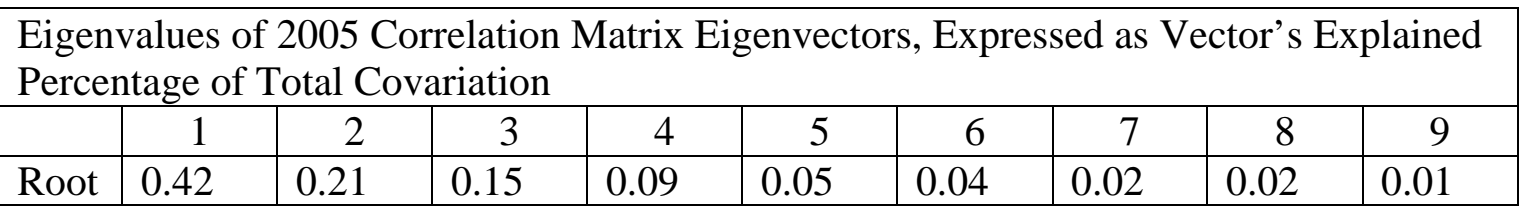


Table 6

\begin{tabular}{|l|r|r|r|r|r|r|r|r|r|}
\hline \multicolumn{2}{|l|}{ Eigenvectors of the 2005 Correlation Matrix } \\
\hline Vector & 1 & 2 & 3 & 4 & 5 & 6 & 7 & 8 & 9 \\
\hline LogA & 0.025 & 0.338 & 0.660 & -0.303 & -0.387 & -0.232 & -0.121 & 0.372 & 0.042 \\
\hline LA & 0.451 & -0.193 & -0.249 & 0.050 & 0.013 & -0.269 & 0.159 & 0.455 & 0.625 \\
\hline NEAA & -0.281 & -0.431 & 0.054 & 0.391 & -0.679 & 0.138 & -0.194 & -0.077 & 0.239 \\
\hline IIA & 0.176 & -0.332 & -0.295 & -0.767 & -0.367 & 0.070 & 0.030 & -0.122 & -0.167 \\
\hline NIIA & 0.325 & -0.443 & 0.265 & 0.081 & 0.234 & 0.433 & -0.318 & 0.422 & -0.317 \\
\hline OOIA & -0.348 & -0.326 & 0.296 & -0.351 & 0.438 & -0.058 & -0.280 & -0.217 & 0.491 \\
\hline PEA & 0.358 & -0.190 & 0.497 & 0.069 & -0.019 & 0.148 & 0.620 & -0.413 & 0.082 \\
\hline PEEMP & -0.351 & -0.453 & 0.070 & 0.052 & 0.088 & -0.564 & 0.358 & 0.253 & -0.383 \\
\hline
\end{tabular}

Table 7 displays the changes in the opacity measures from year to year. As the table indicates, there was little change in the values or the ranks. Under the cluster hypothesis, our measure of opacity should produce both higher excess return and greater risk as opacity rises. Table 8 provides 2005 innovative opacity rank along with the annualized monthly four year 2002-2005 average of total returns to investing in the stock of the institutions in our sample (monthly returns provided by Datastream). 
Table 7

\begin{tabular}{|c|c|c|c|c|c|c|c|c|}
\hline \multicolumn{9}{|c|}{ Annual Institutional Opacity Scores and Ranks, 2002-2005 } \\
\hline & \multicolumn{2}{|c|}{2005} & \multicolumn{2}{|c|}{2004} & \multicolumn{2}{|c|}{2003} & \multicolumn{2}{|c|}{2002} \\
\hline Bank & $\begin{array}{l}\text { Opacity } \\
\text { Score }\end{array}$ & $\begin{array}{l}\text { Opacity } \\
\text { Rank }\end{array}$ & $\begin{array}{l}\text { Opacity } \\
\text { Score }\end{array}$ & $\begin{array}{l}\text { Opacity } \\
\text { Rank }\end{array}$ & $\begin{array}{l}\text { Opacity } \\
\text { Score }\end{array}$ & $\begin{array}{l}\text { Opacity } \\
\text { Rank }\end{array}$ & $\begin{array}{l}\text { Opacity } \\
\text { Score }\end{array}$ & $\begin{array}{l}\text { Opacity } \\
\text { Rank }\end{array}$ \\
\hline ANZ & 2.32 & 6 & 2.60 & 0 & 2.37 & 6 & 1.40 & 7 \\
\hline WestPac & 1.65 & 8 & 1.94 & 8 & 1.42 & 9 & 1.00 & 10 \\
\hline Macquarie & 4.32 & 2 & 4.08 & 2 & 3.50 & 2 & 3.70 & 4 \\
\hline $\begin{array}{c}\text { Nat'l Australia } \\
\text { Bank }\end{array}$ & 1.19 & 13 & 1.49 & 12 & 1.04 & 18 & 0.73 & 14 \\
\hline Commonwealth & 1.53 & 10 & 1.45 & 13 & 1.28 & 12 & 0.60 & 18 \\
\hline Goldman Sachs & 4.66 & 1 & 4.97 & 1 & 4.90 & 1 & 4.33 & 1 \\
\hline $\begin{array}{l}\text { Bank of } \\
\text { America }\end{array}$ & 0.94 & 16 & 0.86 & 18 & 1.10 & 16 & 0.64 & 17 \\
\hline Citibank & 0.12 & 26 & 0.27 & 24 & 0.40 & 23 & 0.24 & 22 \\
\hline JP Morgan & 0.16 & 25 & 0.26 & 26 & 0.52 & 22 & 0.80 & 13 \\
\hline Lehman & 3.36 & 3 & 3.39 & 3 & 3.34 & 5 & 4.08 & 2 \\
\hline Merrill & 2.96 & 4 & 3.24 & 4 & 3.42 & 3 & 3.75 & 3 \\
\hline Morgan Stanley & 2.74 & 5 & 3.08 & 5 & 3.39 & 4 & 3.29 & 5 \\
\hline Wachovia & 0.12 & 27 & 0.31 & 23 & 0.22 & 26 & 0.20 & 23 \\
\hline Wells & 0.68 & 20 & 0.74 & 19 & 1.20 & 13 & 0.27 & 21 \\
\hline HBOS & 2.07 & 7 & 2.14 & 7 & 1.32 & 11 & 3.13 & 6 \\
\hline Barclays & 0.29 & 23 & 1.01 & 16 & 0.29 & 24 & 0.08 & 27 \\
\hline HSBC & 1.43 & 12 & 1.61 & 11 & 1.36 & 10 & 0.90 & 12 \\
\hline Lloyds & 1.19 & 14 & 1.08 & 14 & 1.18 & 14 & 0.50 & 19 \\
\hline $\begin{array}{l}\text { Royal Bank of } \\
\text { Scotland }\end{array}$ & 0.76 & 19 & 0.68 & 20 & 1.79 & 7 & 0.20 & 24 \\
\hline $\begin{array}{c}\text { Bank of Nova } \\
\text { Scotia }\end{array}$ & 1.62 & 9 & 1.77 & 9 & 0.14 & 27 & 1.32 & 8 \\
\hline $\begin{array}{c}\text { Bank of } \\
\text { Montreal }\end{array}$ & 0.31 & 22 & 0.22 & 27 & 0.67 & 21 & 0.49 & 20 \\
\hline $\begin{array}{c}\text { Canadian } \\
\text { Imperial }\end{array}$ & 0.26 & 24 & 0.26 & 25 & 0.28 & 25 & 0.72 & 15 \\
\hline $\begin{array}{c}\text { Toronto } \\
\text { Dominion }\end{array}$ & 0.86 & 17 & 0.51 & 22 & 0.28 & 25 & 0.72 & 15 \\
\hline $\begin{array}{l}\text { Nat'l Bank of } \\
\text { Canada }\end{array}$ & 0.32 & 21 & 0.53 & 21 & 0.82 & 20 & 0.18 & 25 \\
\hline $\begin{array}{l}\text { Royal Bank of } \\
\text { Canada }\end{array}$ & 0.81 & 18 & 1.00 & 17 & 1.66 & 8 & 0.90 & 11 \\
\hline Allied Irish & 1.53 & 11 & 1.61 & 10 & 1.08 & 17 & 1.13 & 9 \\
\hline Bank of Ireland & 1.09 & 15 & 1.06 & 15 & 1.11 & 15 & 0.68 & 16 \\
\hline
\end{tabular}


Table 8

Data Used to Compare Opacity to Long Run Average Returns

\begin{tabular}{|c|c|c|}
\hline Bank & 2005 Opacity & 2002-2005 Average Returns \\
\hline ANZ & 2.316 & 0.159 \\
\hline WestPac & 1.651 & 0.149 \\
\hline Macquarie & 4.317 & 0.350 \\
\hline Nat'l Australia Bank & 1.191 & 0.083 \\
\hline Commonwealth & 1.534 & 0.162 \\
\hline Goldman Sachs & 4.659 & 0.222 \\
\hline Bank of America & 0.940 & 0.165 \\
\hline Citibank & 0.124 & 0.062 \\
\hline JP Morgan & 0.164 & 0.062 \\
\hline Lehman & 3.365 & 0.291 \\
\hline Merrill & 2.965 & 0.126 \\
\hline Morgan Stanley & 2.735 & 0.144 \\
\hline Wachovia & 0.116 & 0.165 \\
\hline Wells & 0.683 & 0.149 \\
\hline HBOS & 2.067 & 0.163 \\
\hline Barclays & 0.285 & 0.160 \\
\hline HSBC & 1.428 & 0.078 \\
\hline Lloyds & 1.186 & 0.205 \\
\hline Royal Bank of Scotland & 0.762 & 0.198 \\
\hline Bank of Nova Scotia & 1.617 & 0.190 \\
\hline Bank of Montreal & 0.315 & 0.189 \\
\hline Canadian Imperial & 0.261 & 0.210 \\
\hline Toronto Dominion & 0.861 & 0.184 \\
\hline Nat'l Bank of Canada & 0.316 & 0.196 \\
\hline Royal Bank of Canada & 0.809 & 0.096 \\
\hline Allied Irish & 1.527 & 0.074 \\
\hline Bank of Ireland & 1.094 & 0.110 \\
\hline
\end{tabular}


Chart 1 is the associated scatter diagram. The resulting regression is found in Table 9.

Chart 1

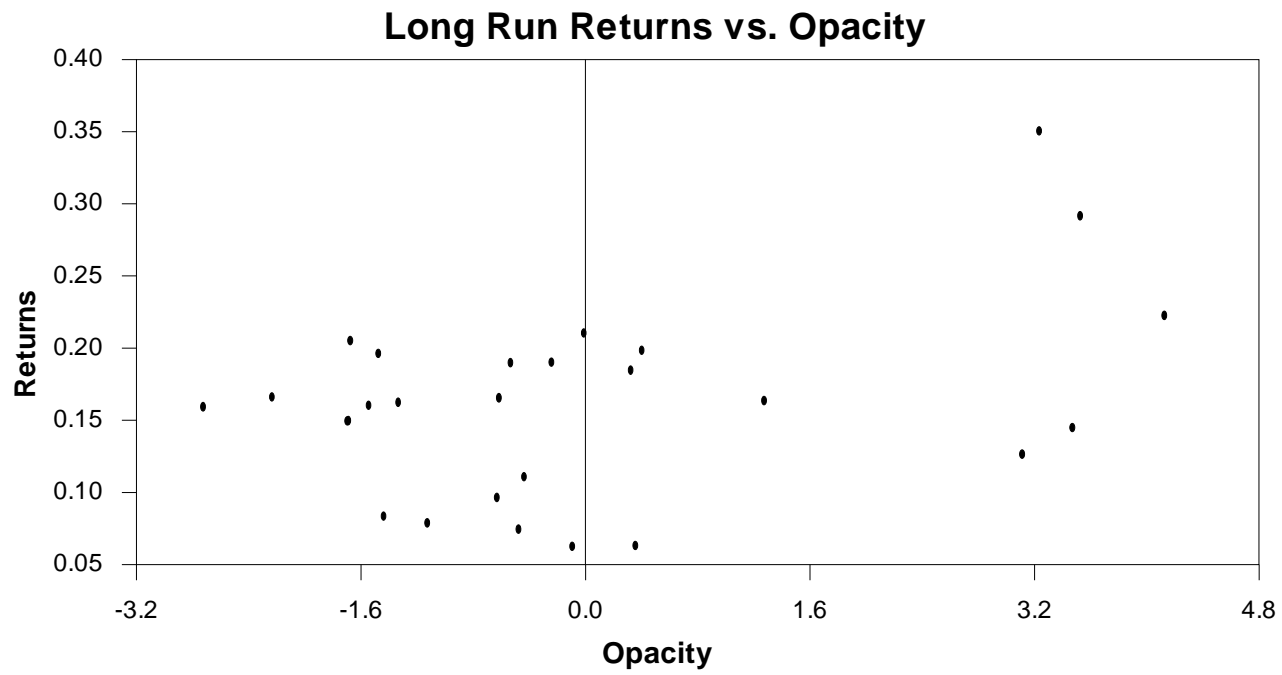

Table 9

\begin{tabular}{|l|l|l|l|l|l|}
\hline \multicolumn{2}{|c|}{ Regression Results, 2002-2005 Monthly Average returns vs. Opacity Measure } \\
\hline $\begin{array}{l}\text { Regression } \\
\text { Statistics }\end{array}$ & & & & & \\
\hline Multiple R & 0.499 & & & & \\
\hline R Square & 0.249 & & & & \\
\hline $\begin{array}{l}\text { Adjusted R } \\
\text { Square }\end{array}$ & 0.219 & & & & \\
\hline $\begin{array}{l}\text { Standard } \\
\text { Error }\end{array}$ & 0.058 & & & & \\
\hline Observations & 27 & & & & \\
\hline & & & & & \\
\hline ANOVA & & & & & \\
\hline & $\mathrm{df}$ & SS & MS & F & Significance of F \\
\hline Regression & 1 & 0.0284 & 0.0284 & 8.3047 & 0.0080 \\
\hline Residual & 25 & 0.0855 & 0.0034 & & \\
\hline Total & 26 & 0.1140 & & & \\
\hline \multicolumn{7}{|l|l|l|l|}{} & Coefficients & $\begin{array}{l}\text { Standard } \\
\text { Error }\end{array}$ & T Stat & P-value & \\
\hline & 0.122 & 0.017 & 6.969 & $2.63 E-07$ & \\
\hline Intercept & 0.026 & 0.009 & 2.881 & 0.008 & \\
\hline Opacity & 0.008 & & \\
\hline
\end{tabular}


The regression indicates innovation has strong (significant at the $1 \%$ level) explanatory value in identifying long run returns to investing in the common stock of financial institutions.

\section{Conclusion.}

This article sets out a stylized characterization of the innovation process within financial institutions. This description, the cluster hypothesis, provides an explanation for the failure of financial markets to capitalize financial innovation announcements immediately into equity valuation that is nonetheless consistent with the existence of innovation-based rents. Some innovations in the cluster are transparent but therefore not profitable to the innovating firms; others are opaque and thus potentially profitable, but not observable. The article suggests that there may be some relationship between 2005 deviations from mean sample values of the reporting variables we consider and average returns to the institutions' common stock over the four year period from 2002-2005. 


\section{Bibliography}

Frame, W. S., and L. J. White, (2004), "Empirical Studies of Financial Innovation: Mostly Talk and Not Much Action?,” Journal of Economic Literature 42: 116-144.

Frankel, Tamar, (1998), “Cross-border Securitization: Without Law, But Not Lawless,” Duke Journal of Comparative and International Law 8 (Spring): 255-282.

Jaffe, Adam and Josh Lerner, (2004), Innovation and Its Discontents, NJ: Princeton University Press.

Kane, Edward, (2000), "Incentives for Banking Megamergers: What Incentives Might Regulators Infer from Event Study Evidence?,” Journal of Money, Credit, and Banking 32(3), (August, Part 2): 671-701.

Kumar, Praveen and Stuart Turnbull, (2006), "Patenting and Licensing of Financial Innovations,” July, Available at SSRN: http://ssrn.com/abstract=917874

Lerner, Josh, (2006a), “The New Financial Thing: The Origins of Financial Innovations,” Journal of Financial Economics 76: 223-255.

Lerner, Josh, (2006b), "Where Does State Street Lead? A First Look at Finance Patents, 1971-2000,” Journal of Finance 57: 901-930.

Liu, Qiao, (2000), "How Good is Good News? Technology, Depth, Book-to-Market Ratios, and Innovative Events," April, Available at DOI: 10.2139/ssrn.248909 or SSRN: http://ssrn.com/abstract=248909.

Merton, R.C., (1992), “Financial Innovation and Economic Performance,” Journal of Applied Corporate Finance 4: 12-22.

Miller, Merton H., (1986), "Financial Innovation: The Last Twenty Years and the Next," Journal of Financial and Quantitative Analysis 21: 459-471.

Ross, S. A., (1999), “Lessons from Two Decades in the Risk Management Morgue,” Risk 12 (5), (May): 64-66.

Saunders, Anthony, and Linda Allen, (2002), Credit Risk Measurement, NJ: John Wiley and Sons.

Tufano, Peter, (1989), “Financial Innovation and First-mover Advantages,” Journal of Financial Economics 25: 213-240. 
Tufano, Peter, (2003), "Financial Innovation,” in George Constantinides, Milton Harris, and Rene Stulz, eds.: Handbook of the Economics of Finance (Amsterdam: North Holland).

Shelanski, H., (2003), “The Uninvited Guest: Patents on Wall Street,” Federal Reserve Bank of Atlanta Economic Review, 4th Quarter. 